\title{
EFFICACY OF CHEMICALLY CHARACTERIZED CARUM COPTICUM ESSENTIAL OIL AS AN ANTIOXIDANT AND LIPID PEROXIDATION INHIBITION
}

\author{
M. Kazemi* \\ Department of Horticultural Science, College of Agricultural Science and Natural Resources, \\ Tehran Science and Research Branch, Islamic Azad University, Tehran, Iran
}

\begin{abstract}
The study reports potential of Carum copticum seed essential oil (EO) as a plant based shelf life enhancer against contamination and lipid peroxidation. Also, the effect of exogenous application of nano iron chelate on components of essential oils (Eos) of Ca.copticum was evaluated. The nano iron chelate application increased $\gamma$ - terpinene and thymol concentration. Thymol exhibit a higher activity in each antioxidant system with a special attention for b-carotene bleaching test (IC50: 11.30 $0.45 \mu \mathrm{g} / \mathrm{ml}$ ), lipid peroxidation inhibition $(60.11 \pm 0.27 \mu \mathrm{g} / \mathrm{ml})$ and reducing power (EC50: $9.24 \pm 0.12 \mu \mathrm{g} / \mathrm{ml})$. These results indicate that Ca.copticum $\mathrm{EO}$ and its main compounds might be applicable in natural medicine and healthy food.
\end{abstract}

Key words: Carum copticum; essential oil; lipid peroxidation; antioxidant.

\section{INTRODUCTION}

Oxidation of lipid during processing and storage affect food quality causing qualitative deterioration of the treated commodities because of chemical spoilage, rancidity, changing their color and texture (1). Free radicals or reactive oxygen species have been shown to be the causative agent in aging and several degenerative diseases such as cancer, atherogenesis, heart and neurodegenerative diseases (2). Antioxidant compounds, such as phenolics, organic acids, vitamin $\mathrm{E}$, and carotenoids scavenge free radicals, thus inhibiting the oxidative mechanisms that may lead to degenerative illnesses (3). Phenolic compounds may serve this purpose by reducing or donating hydrogen to other compounds, scavenging free radicals, and quenching singlet oxygen (4). Generally, the EOs possessing the strongest antioxidant activities against oxidation of lipid contain a high percentage of phenolic compounds such as carvacrol, eugenol, isoeugenol and thymol.The present study was

\footnotetext{
*Correspondence to: M. Kazemi, Department of Horticultural Science, Faculty of Agricultural Science and Natural Resources, Tehran Science and Research Branch, Islamic Azad University, Tehran, Iran, E-mail:mokazemi64@gmail.com
}

performed to investigate application of nano iron chelate on components of essential oils $C a$. copticum and to evaluate the efficacy of chemically characterized $\mathrm{Ca}$. copticum essential oil as antioxidant and lipid peroxidation inhibition agent.

\section{MATERIALS AND METHODS}

Two separate sets of experiments were conducted in a completely randomized design. In the first set, the effect of exogenous application of nano iron chelate (150 and $\left.250 \mathrm{mgL}^{-1}\right)$ in early flowering stage on components of Eos of $C a$. copticum was evaluated. The second set included investigating the effect of nano iron chelat at $200 \mathrm{mgL}^{-1}$ on antioxidant capacity and lipid peroxidation inhibition.

\section{Plant materials and nano iron chelate treatments}

Seeds of Ca. copticum were sown in Jefe pot in experimental greenhouse of Ilam, Iran. Plants at flowering stage (2013-2014) were sprayed with distilled water as a control, and nano iron chelate at 150 and $250 \mathrm{mg} \mathrm{L}^{-1}$. All sprays solution were sprayed to the point of run off. The experiment was arranged in completely randomized block design with three replications for each treatment. At seed stage of Ca. copticum were harvested 
and air dried at ambient temperature in the shade.

\section{Oil isolation and identification of the oil components}

The Ca. copticum seeds were ground and the resulting powder was subjected to hydrodistillation for 3 hours in an all glass Clevenger-type apparatus according to the method recommended by the European Pharmacopoeia (5). The obtained essential oils were dried over anhydrous sodium sulphate and after filtration, stored at $+4{ }^{\circ} \mathrm{C}$ until tested and analysed. The GC/MS analyses were executed on a Hewlett-Packard 5973N gas chromatograph equipped with a column HP-5MS (30 m length $\times$ $0.25 \mathrm{~mm}$ i.d., film thickness $0.25 \mathrm{~lm}$ ) coupled with a Hewlett-Packard 5973N mass spectrometer. The column temperature was programmed at $50{ }^{\circ} \mathrm{C}$ as an initial temperature, holding for $6 \mathrm{~min}$, with $3{ }^{\circ} \mathrm{C}$ increases per minute to the temperature of $240{ }^{\circ} \mathrm{C}$, followed by a temperature enhancement of $15^{\circ} \mathrm{C}$ per minute up to $300{ }^{\circ} \mathrm{C}$, holding at the mentioned temperature for $3 \mathrm{~min}$. Injector port temperature was $290{ }^{\circ} \mathrm{C}$ and helium used as carrier gas at a flow rate 1.5 $\mathrm{ml} / \mathrm{min}$. Ionization voltage of mass spectrometer in the EI-mode was equal to $70 \mathrm{eV}$ and ionization source temperature was $250{ }^{\circ} \mathrm{C}$. Linear retention indices for all components were determined by coinjection of the samples with a solution containing homologous series of C8C22 n-alkanes and comparing them and their mass spectra with those of authentic samples or with available library data of the GC/MS system (WILEY 2001 data software) and Adams libraries spectra (6).

\section{Total phenolic determination}

Total phenolic contents in seeds $\mathrm{Ca}$. copticum were determined by Folin-Ciocalteu method (7). The total phenolic content was expressed as gallic acid equivalents (GAE) $\left(\mathrm{mg} \mathrm{g}^{-1}\right)$.

\section{Total flavonoid determination}

Total flavonoid contents in seeds $\mathrm{Ca}$. copticum were measured as described previously (8). The total flavonoid content was calculated as rutin equivalents $\left(\mathrm{mg} \mathrm{g}^{-1}\right)$.

\section{Antioxidant activity}

The efficacy of the essential oils to scavenge 2,2-diphenyl-1-picrylhydrazyl (DPPH) radicals was evaluated using a spectrophotometry method $(9,10)$. On basis of bleaching of the bluish-red or purple colour of DPPH solution as a reagent. Briefly, a $50 \mu 1$ volume of various dilutions of each samples was mixed with $5 \mathrm{ml}$ of $0.004 \%$ methanol solutions of DPPH followed by 30 min incubation at ambient temperature. Thereafter, the sample absorbance was recorded against control at $517 \mathrm{~nm}$. The inhibition percentages were measured using Eq. (1). The antioxidants activity of the test samples in concentration providing 50\% inhibition, were considered as IC50 $(\mu \mathrm{g} / \mathrm{ml})$.

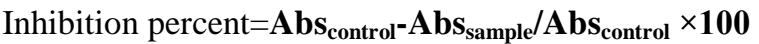

Butylhydroxyanisole (BHA) and ascorbic acid were used as positive controls. All experiments were repeated three times and the average results and standard deviations calculated.

\section{Rapid screening for antioxidants}

For screening of antioxidant compounds in $\mathrm{Ca}$. copticum essential oil, the TLC-bioautography method was carried out $(11,12)$. The diluted oil (1:20 in methanol) was spotted on silica gel sheets (silica gel 60 F254 TLC plates) and developed in n-hexane-ethyl acetate (9:1). Plates were sprayed with the methanolic solution of $\mathrm{DPPH} \bullet(0.2 \%)$. The active constituents were detected as yellow spots on a violet background. Only zones where their color turned from violet to yellow within the first 30 min (after spraying) were taken as positive results.

\section{Activity guided fractionation of the essential oil for antioxidants}

For the isolation and identification of the active compounds in the essential oil, TLC was performed using the conditions previously described (12). The regions showing DPPH• scavenging activity were scrapped off then, they were eluted with chloroform. All resulting constituents were analyzed by GC/MS and also tested for their antioxidant activities.

\section{b-Carotene-linoleic acid model system (- CLAMS)}

The b-CLAMS method by the peroxides generated during the oxidation of linoleic acid at elevated temperature (13). The antioxidant activity (AA) of the extracts was evaluated in term of $\mathrm{b}$-carotene blanching using the following formula: $\mathrm{AA}(\%)=\left[\left(\mathrm{A}_{0^{-}} \mathrm{A}_{1}\right) / \mathrm{A}_{0}\right]^{*} 100$. where $\mathrm{A}_{0}$ is the absorbance of the control at 0 min, and $\mathrm{A} 1$ is the absorbance of the sample at $120 \mathrm{~min}$. The results are expressed as IC50 values $(\mu \mathrm{g} / \mathrm{ml})$. All samples were prepared and analyzed in triplicate.

\section{Reducing power and lipid peroxidation inhibition}

The ability of the extracts to reduce $\mathrm{Fe}^{3+}$ was assayed by the method of Oyaizu (14). $1 \mathrm{ml}$ of 
Ca. copticum essential oil were mixed with 2.5 $\mathrm{ml}$ of phosphate buffer $(0.2 \mathrm{M}, \mathrm{pH} 6.6)$ and 2.5 $\mathrm{ml}$ of $1 \% \mathrm{~K}_{3} \mathrm{Fe}(\mathrm{CN}) 6$. After incubation at $50{ }^{\circ} \mathrm{C}$ for $25 \mathrm{~min}, 2.5 \mathrm{ml}$ of $10 \%$ trichloroacetic acid was added and the mixture was centrifuged at $650 \mathrm{~g}$ for $10 \mathrm{~min}$. Finally, $2.5 \mathrm{ml}$ of the upper layer was mixed with $2.5 \mathrm{ml}$ of distilled water and $0.5 \mathrm{ml}$ of $0.1 \%$ aqueous $\mathrm{FeCl}_{3}$. The absorbance was measured at $700 \mathrm{~nm}$. The mean of absorbance values were plotted against concentration and a linear regression analysis was carried out. Increase absorbance of the reaction mixture indicated increased reducing power. EC50 value $(\mu \mathrm{g} / \mathrm{ml})$ is the effective concentration at which the absorbance was 0.5 for reducing power. Ascorbic acid was used as positive control. Lipid peroxidation inhibition was determined by Shirwaikar et al., (15). Ascorbic acid and trolox were used for comparison.

\section{Statistical analysis}

The results are presented as mean \pm S.D and statistically analyzed by oneway analysis of variance (ANOVA) followed by Duncan test.
RESULTS AND DISCUSSION

Effect of nano iron chelate on chemical composition of Ca.copticum $\mathrm{EO}$

The GC/MS analysis of Ca. copticum oil revealed 14 compounds representing $79.25 \%$ of the total oil; $\gamma$-terpinene was the main constituent (28.74\%.), followed by p-cymene (20.21\%), thymol $(14.35 \%)$ and $\alpha$-pinene $(6.21 \%)$. The constituents of the obtained Eos of Ca. copticum treated with nano iron chelate are presented in Table 1. Fourteen components were identified in untreated plants and eleven components in nano iron chelate -treated plants (Table 1). The differences were supposed to be the effects of nano iron chelate on chemical composition of Ca.copticum EO. Limonene, $\gamma$ - terpinene and thymol were increased with nano iron chelatetreatment (Table 1). The yield of the $C a$. copticum oil was $1.30 \%$ in control, $2.00 \%$ (150 $\left.\mathrm{mgL}^{-1}\right)$ and $2.81 \%\left(250 \mathrm{mgL}^{-1}\right)$. Nano iron chelate significantly increased the yield of EO (Table 1).

Table 1. Effect of nano iron chelate on chemical composition of Ca.copticum essential oil.

\begin{tabular}{|c|c|c|c|c|c|c|}
\hline & \multirow[b]{2}{*}{ Components } & \multicolumn{3}{|c|}{${ }^{a}$ Ca.copticum EO (\%) } & \multirow[b]{2}{*}{$\begin{array}{c}{ }^{\mathrm{b}} \text { Retention } \\
\text { Index }\end{array}$} & \multirow[b]{2}{*}{$\begin{array}{c}\text { Identification } \\
\text { Methods }\end{array}$} \\
\hline & & $\begin{array}{c}\text { Control } \\
(\%)\end{array}$ & $\begin{array}{l}\text { Nano iron } \\
\text { chelate }(150 \\
\left.\mathrm{mgL}^{-1}\right)(\%)\end{array}$ & $\begin{array}{l}\text { Nano iron } \\
\text { chelate }(250 \\
\left.\mathrm{mgL}^{-1}\right)(\%)\end{array}$ & & \\
\hline 1 & $\alpha$-thujene & 0.41 & - & & 850 & MS, RI \\
\hline 2 & $\alpha$-pinene & 6.21 & 3.21 & 2.14 & 855 & MS, RI \\
\hline 3 & $\beta$-pinene & 1.00 & 0.41 & 0.22 & 190 & MS, RI \\
\hline 4 & $\beta$-myrcene & 1 & $\ldots$ & - & 920 & MS, RI \\
\hline 5 & $P$-cymene & 20.21 & 16.54 & 13.24 & 950 & MS, RI \\
\hline 6 & $\beta$-phellendrene & 3.54 & - & - & 954 & MS, RI \\
\hline 7 & limonene & 0.12 & 3.14 & 3.48 & 960 & MS, RI \\
\hline 8 & $\gamma-$ terpinene & 28.74 & 38.47 & 42.25 & 980 & MS, RI \\
\hline 9 & 4-terpineol & 2.14 & 1.54 & 1.00 & 1.63 & MS, RI \\
\hline 10 & cis limonene oxide & - & - & 0.28 & 1085 & MS, RI \\
\hline 11 & dodecane & $\overline{-}_{-}$ & 0.58 & 1.25 & 1110 & MS, RI \\
\hline 12 & $\beta$-fenchyl alcohol & $0 . \overline{11}$ & - & - & 1126 & MS, RI \\
\hline 13 & thymol & 14.35 & 20.14 & 23.61 & 1208 & MS, RI \\
\hline 14 & $\begin{array}{c}\text { Ethylene } \\
\text { methacrylate }\end{array}$ & 1.00 & 0.22 & 0.10 & 1235 & MS, RI \\
\hline 15 & pentadecane & $=$ & 0.57 & 0.74 & 1264 & MS, RI \\
\hline 16 & hexadecane & 0.11 & 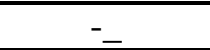 & - & 1285 & MS, RI \\
\hline 17 & nonadecane & 0.31 & $=-$ & - & 1293 & MS, RI \\
\hline \multirow[t]{3}{*}{18} & carvacrol & - & 5.12 & $8 . \overline{24}$ & 1306 & MS, RI \\
\hline & Total & 79.25 & 89.94 & 96.55 & & \\
\hline & Yield & $1.30 \%$ & $2.00 \%$ & $2.81 \%$ & & \\
\hline
\end{tabular}

${ }^{\mathrm{a}}$ Percentage composition determined on column HP 5. ${ }^{\mathrm{b}}$ The retention Kovats indices were determined on HP 5 capillary column in reference to $n$-alkanes. MS= Mass Spectroscopy, RI= Retention Index. 
Lu et al., (16) have shown that application of nano fertilizers could increase the nitrate reductase enzyme in soybean (Glycine $\max$ L.), increase its abilities of absorbing and utilizing water and fertilizer, promote its antioxidant system, and, in fact, accelerate its germination and growth.

\section{Effect of nano iron chelate on extraction yield, total phenolic contents and total flavonoid contents}

It is well-known that phenolic compounds contribute to quality and nutritional value in terms of modifying color, taste, aroma, and flavor and also in providing health-benefical effects (17). As shown in Table 2, the extraction yield of $\mathrm{Ca}$. copticum ranged from lowest $85.21 \pm 22 \mathrm{mgg}^{-1}$ (control) to highest $131.12 \pm 07$ $\mathrm{mgg}^{-1}$ (nano iron chelate (250 mg L $\left.\mathrm{L}^{-1}\right)$ ) $(\mathrm{P} \leq 0.05)$. Among the three Ca. copticum extracts, Ca. copticum treated with nano iron chelate at $250 \mathrm{mg} \mathrm{L}^{-1}$ showed the highest total phenolic content $\left(300.15 \pm 47 \mathrm{mgg}^{-1}\right)$ and showed the highest total flavonoid content $(187.33 \pm 07$ $\left.\mathrm{mg} \mathrm{g}^{-1}\right)(\mathrm{P} \leq 0.05)$. Furthermore, the total phenolic and total flavonoid contents exhibited the descending order among: $\mathrm{Ca}$. copticum extract (treated with nano iron chelate $250 \mathrm{mg} \mathrm{L}^{-1}$ ) > Ca. copticum extract (treated with nano iron chelate $150 \mathrm{mg} \mathrm{L}^{-1}$ ) > Ca. copticum extract (treated with control) $(\mathrm{P} \leq 0.05)$. These results showed that the total phenolic and total flavonoid contents have an obvious variation in various concentrations.

Table 2. Effect of nano iron chelate on extraction yields, total phenolic contents and total flavonoid contents of Ca.copticum extracts.

\begin{tabular}{ccccc}
\hline & Extract & $\begin{array}{c}\text { Extraction } \\
\text { yield }^{\mathrm{a}}\end{array}$ & $\begin{array}{c}\text { Total } \\
\text { phenolic }^{\mathrm{b}}\end{array}$ & $\begin{array}{c}\text { Total } \\
\text { flavonoid }^{\mathrm{c}}\end{array}$ \\
\hline 1 & Control & $85.21 \pm 22$ & $200.07 \pm 37$ & $94.07 \pm 29$ \\
\hline 2 & $\begin{array}{c}\text { Nano iron chelate }(150 \\
\left.\mathrm{mgL}^{-1}\right)\end{array}$ & $110.14 \pm 74$ & $241.01 \pm 35$ & $110.47 \pm 65$ \\
\hline 3 & $\begin{array}{c}\text { Nano iron chelate }(250 \\
\left.\mathrm{mgL}^{-1}\right)\end{array}$ & $131.12 \pm 07$ & $300.15 \pm 47$ & $187.33 \pm 07$ \\
\hline
\end{tabular}

The data are expressed as mean \pm SD. ${ }^{a}$ Expressed as $m g$ of extract per gr dry material. ${ }^{b}$ Expressed as $\mathrm{mg}$ of gallic acid per gr dry extract. ${ }^{\circ}$ Expressed as $\mathrm{mg}$ of rutin per gr dry extract. Statistically, the differences were significant at $\mathrm{p} \leq 0.05$ using Duncan test.

\section{Antioxidant activity}

The results presented in Table 3 revealed that Ca. copticum EO and its main constituents exhibited a remarkable activity. In particular, thymol exhibited clearly a higher activity $(9.6 \pm$ $0.12 \mu \mathrm{g} / \mathrm{ml}$ ) followed by Ca. copticum EO $(11.89 \pm 0.21 \mu \mathrm{g} / \mathrm{ml}), \gamma$ - terpinene $(11.78 \pm 0.02$ $\mu \mathrm{g} / \mathrm{ml})$ and carvacrol $(11.68 \pm 0.07 \mu \mathrm{g} / \mathrm{ml})$ (Table 3) $(\mathrm{P} \leq 0.05)$, while the activities of other terpenoids were weak ( $\alpha$-pinene and p-cymene) .The positive controls BHT and ascorbic acid exhibited IC50 values equal to $12.11 \pm 0.09$ $\mu \mathrm{g} / \mathrm{ml}$ and $12.38 \pm 0.11 \mu \mathrm{g} / \mathrm{ml}$, respectively $(\mathrm{P} \leq 0.05)$. The monoterpene hydrocarbons, $\mathrm{p}$ cymene and b-pinene were inactive (Table 3), despite previous reports of their in vitro antioxidant activities (18). Table 3 depicts the inhibition of b-carotene bleaching by the $\mathrm{Ca}$. copticum EO. The $\mathrm{IC}_{50}$ value was $10.12 \pm 0.21$ $\mu \mathrm{g} / \mathrm{ml}$. Table 3, the reducing power of $\mathrm{Ca}$. copticum $\mathrm{EO}$, expressed as $\mathrm{CE}_{50}$, was clearly more significant than that of the positive control BHA $(\mathrm{P} \leq 0.05)$. Because of high antioxidant and free radical-scavenging activities of $\mathrm{Ca}$. copticum EO, further investigation was carried out to identify its active constituents. Therefore, a preliminary screening was initially carried out using the dot-blot DPPH stainingmethod on TLC. As the EO presented a significant antioxidant activity in the assays and bioautography test, it was subjected to the TLC for isolation of the active compounds. Components identified and their antioxidant activity relative percentages have been shown in Table 4. The major compound found in the

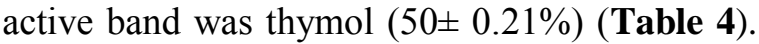
Many aroma components of essential oils, such as terpenes and terpenoids, were proposed to contribute to the antioxidant activity of essential oils ; including thymol and eugenol, linalool and 1,8-cineole. According to these results, there is a relationship between total phenolic contents and antioxidant activity.

\section{Lipid peroxidation inhibition}

According to the results obtained, $\mathrm{Ca}$. copticum EO and its main component significantly inhibited the formation of TBARS in brain homogenates in a concentration-dependent manner (Table 5). The suppressive power on the lipid peroxidation of $\mathrm{Ca}$. copticum EO and were thymol found to be the most potent $(55.31 \pm 0.14$ 
and $51.24 \pm 0.34 \mu \mathrm{g} / \mathrm{ml})$, followed by $\gamma$ terpinene $(60.11 \pm 0.21 \mu \mathrm{g} / \mathrm{ml})$ and carvacrol $(60.33 \pm 0.04 \mu \mathrm{g} / \mathrm{ml})(\mathrm{P} \leq 0.05)$. Ascorbic acid and trolox showed significant suppressive power on lipid peroxidation in mice brain homogenate with IC50 value of $60.38 \pm 0.47$ and $59.35 \pm 0.18$ (Table 5) $(\mathrm{P} \leq 0.05)$. Phenolics are important components of the human diet due to their potential antioxidant activity, their capacity to diminish oxidative stress induced tissue damage resulted from chronic diseases and their potentially important properties such as anticancer activities (19).

Table 3. Antioxidant activity of EO extract from Ca. copticum: scavenging activity (expressed as IC50 values: $\mu \mathrm{g} / \mathrm{ml})$, and b-carotene bleaching test. Reducing power was expressed as EC50 values ( $\mu \mathrm{g} / \mathrm{ml})$. Butylhydroxyanisole (BHA) and ascorbic acid were used as positive controls.

\begin{tabular}{ccc}
\hline & Control & N-N-Ch $250 \mathrm{mg} \mathrm{L}^{-1}$ \\
\cline { 2 - 3 } Tested compounds & $\mathrm{IC} 50(\mu \mathrm{g} / \mathrm{ml})$ & $\mathrm{IC} 50(\mu \mathrm{g} / \mathrm{ml})$ \\
\hline Ca. copticum EO & $18 \pm 0.54 \mu \mathrm{g} / \mathrm{ml}$ & $11.89 \pm 0.21 \mu \mathrm{g} / \mathrm{ml}$ \\
$\alpha$-pinene & $20 \pm 0.43 \mu \mathrm{g} / \mathrm{ml}$ & $15.21 \pm 0.07 \mu \mathrm{g} / \mathrm{ml}$ \\
-cymene & $16.87 \pm 0.89 \mu \mathrm{g} / \mathrm{ml}$ & $13.54 \pm 0.74 \mu \mathrm{g} / \mathrm{ml}$ \\
$\gamma$ - terpinene & $15.32 \pm 0.28 \mu \mathrm{g} / \mathrm{ml}$ & $11.78 \pm 0.02 \mu \mathrm{g} / \mathrm{ml}$ \\
thymol & $13.11 \pm 0.60 \mu \mathrm{g} / \mathrm{ml}$ & $9.6 \pm 0.12 \mu \mathrm{g} / \mathrm{ml}$ \\
carvacrol & $15.83 \pm 0.24 \mu \mathrm{g} / \mathrm{ml}$ & $11.68 \pm 0.07 \mu \mathrm{g} / \mathrm{ml}$ \\
\hline Ca. copticum EO (b-Carotenes IC50 $\mu \mathrm{g} / \mathrm{ml})$ & $14.12 \pm 0.55 \mu \mathrm{g} / \mathrm{ml}$ & $10.12 \pm 0.21 \mu \mathrm{g} / \mathrm{ml}$ \\
Ca. copticum EO (PR EC50 $\mu \mathrm{g} / \mathrm{ml})$ & $14.12 \pm 0.34$ & \\
BHA & $\mu \mathrm{g} / \mathrm{ml}$ & $10.01 \pm 0.07 \mu \mathrm{g} / \mathrm{ml}$ \\
AA & $14 \pm 0.05 \mu \mathrm{g} / \mathrm{ml}$ & $12.11 \pm 0.09 \mu \mathrm{g} / \mathrm{ml}$ \\
\hline
\end{tabular}

Control: Plants treated with distilled water. EO: Essential oil. N-N-Ch 250: Plants treated nano iron chelate $250 \mathrm{mg}$ $\mathrm{L}^{-1}$. Values are mean \pm S.D. of three replications. ${ }^{*}$ IC50 values have been presented with their respective $95 \%$ confidence limits. Statistically, the differences were significant at $p \leq 0.05$ using Duncan test.

Table 4. Components identified and their antioxidant activity relative percentages.

\begin{tabular}{ccc}
\hline & Control & $\mathrm{N}-\mathrm{N}-\mathrm{Ch} 250 \mathrm{mg} \mathrm{L}^{-1}$ \\
\cline { 2 - 3 } compounds & $\%$ & $\%$ \\
\hline$\alpha$-pinene & $10 \pm 0.43$ & $4 \pm 0.51$ \\
$P$-cymene & $12 \pm 0.87$ & $5 \pm 0.21$ \\
$\gamma$ - terpinene & $10 \pm 0.11$ & $20 \pm 0.41$ \\
carvacrol & $10 \pm 0.45$ & $13 \pm 0.20$ \\
thymol & $30 \pm 0.1$ & $50 \pm 0.21$
\end{tabular}

Control: Plants treated with distilled water. EO: Essential oil. N-N-Ch 250: Plants treated nano iron chelate $250 \mathrm{mg}$ $\mathrm{L}^{-1}$. Results are expressed as a percentage of antioxidant activity relative. Experiments were carried out in triplicate. Statistically, the differences were significant at $\mathrm{p} \leq 0.05$ using Duncan test

Table 5. Lipid peroxidation inhibition of EO extract from Ca. opticum and its main component (expressed as IC50 values: $\mu \mathrm{g} / \mathrm{ml}$ ). Trolox and ascorbic acid (AA) were used as positive controls.

\begin{tabular}{|c|c|c|}
\hline & Control & $\mathrm{N}-\mathrm{N}-\mathrm{Ch} 250 \mathrm{mg} \mathrm{L}^{-1}$ \\
\hline Tested compounds & $\mathrm{IC} 50(\mu \mathrm{g} / \mathrm{ml})$ & $\mathrm{IC} 50(\mu \mathrm{g} / \mathrm{ml})$ \\
\hline Ca. copticum $\mathrm{EO}$ & $\begin{array}{c}71.34 \pm 0.34 \mu \mathrm{g} / \mathrm{ml} \\
130.34 \pm 0.15\end{array}$ & $55.31 \pm 0.14 \mu \mathrm{g} / \mathrm{ml}$ \\
\hline$\alpha$-pinene & $\begin{array}{c}\mu \mathrm{g} / \mathrm{ml} \\
132.21 \pm 0.56\end{array}$ & $88.24 \pm 0.34 \mu \mathrm{g} / \mathrm{ml}$ \\
\hline$P$-cymene & $\mu \mathrm{g} / \mathrm{ml}$ & $90.00 \pm 0.47 \mu \mathrm{g} / \mathrm{ml}$ \\
\hline$\gamma$ - terpinene & $70.54 \pm 0.87 \mu \mathrm{g} / \mathrm{ml}$ & $60.11 \pm 0.21 \mu \mathrm{g} / \mathrm{ml}$ \\
\hline thymol & $68.47 \pm 0.34 \mu \mathrm{g} / \mathrm{ml}$ & $51.24 \pm 0.34 \mu \mathrm{g} / \mathrm{ml}$ \\
\hline carvacrol & $78.29 \pm 0.70 \mu \mathrm{g} / \mathrm{ml}$ & $60.33 \pm 0.04 \mu \mathrm{g} / \mathrm{ml}$ \\
\hline trolox & $62.21 \pm 0.05 \mu \mathrm{g} / \mathrm{ml}$ & $59.35 \pm 0.18 \mu \mathrm{g} / \mathrm{ml}$ \\
\hline AA & $89.54 \pm 0.12 \mu \mathrm{g} / \mathrm{ml}$ & $60.38 \pm 0.47 \mu \mathrm{g} / \mathrm{ml}$ \\
\hline
\end{tabular}

Experiments were carried out in triplicate and the results are expressed as mean \pm S.D. Statistically, the differences were significant at $\mathrm{p} \leq 0.05$ using Duncan test 


\section{CONCLUSION}

There was a good correlation between total phenol content, lipid peroxidation inhibition and antioxidant capacity of the extracts. In conclusion, Ca. copticum extracts appear to contain compounds with lipid peroxidation inhibition and antioxidant activities.

\section{REFERENCES}

1. Erkan, N., Ayranci, G., and Ayranci, E. A kinetic study of oxidation developmentin sunflower oil under microwave heating: Effect of natural antioxidants. Food Research International, Vol. 42, pp. 1171-1177, 2009.

2. Schinella, G., Mosca, S., CienfuegosJovellanos, E., Pasamar, M.Á., Muguerza, B., and Ramón, D. Antioxidant properties of polyphenol-rich cocoa products industrially processed. Food Research International, Vol. 43, pp.1614-1623, 2010.

3. Silva, R.H., Abílio, V.C., Takatsu, A.L., Kameda, S.R., Grassl, C., Chehin, A.B., Medrano, W.A., Calzavara, M.B., Registro, S., Andersen, M.L., Machado, R.B., Carvalho, R.C., Ribeiro, A., Tufik, S., and Frussa-Filho, R. Role of hippocampal oxidative stress in memory deficits induced by sleep deprivation in mice. Neuropharmacology, Vol.46, pp.895-903, 2004.

4. Costa, R.M., Magalhães, A.S., Pereira, J.A., Andrade, P.B., Valentão, P., Carvalho, M., and Silva, B.M. Evaluation of free radicalscavenging and antihemolytic activities of quince (Cydonia oblonga) leaf: a comparative study with green tea (Camellia sinensis). Food Chem. Toxicol, Vol. 47, pp.860-865, 2009.

5. European Pharmacopoeia. Vol. 3, Maisonneuve S. A., Sainte-Ruffine, 1975.

6. Adams, R.P. Identification of Essential Oil Components by Gas Chromatography/Mass Spectroscopy. Allured, Carol Stream, IL, p. 469, 2001.

7. Jimoh, F.O., Sofidiya, M.O., and Afolayan, A.J. Antioxidant properties of the methanol extracts from the leaves of Paullinia pinnata. Journal of Medicinal Food, Vol. 10, pp. 707711, 2007.

8. Piccolella, S., Fiorentino, A., Pacifico, S., D'Abrosca, B., Uzzo, P., and Monaco, P. Antioxidant properties of sour cherries (Prunus cerasus L.): role of colorless phytochemicals from the methanolic extract of ripe fruits. Journal of Agricultural and Food Chemistry, Vol. 56, pp.1928-1935, 2008.
9. Cuendet, M., Hostettmann, K., and Potterat, O. Iridoid glucosides with free radicalm scavenging properties from Fagraea blumei. Helvetica Chimica Acta, Vol. 80,pp.11441152, 1997.

10.Kirby, A.J., and Schmidt, R.J. The antioxidant activity of Chinese herbs for eczema and of placebo herbs - I. Journal of Ethnopharmacology, Vol. 56,pp. 103-108, 1997.

11.Burits, M., \& Bucar, F. Antioxidant activity of Nigella sativa essential oil. Phytother. Res, 14,323-328, 2000.

12.Guleria, S., Tiku, A., Gupta, S., Singh, G., Koul, A., \& Razdan, V. Chemical composition, antioxidant activity and inhibitory effects of essential oil of Eucalyptus teretecornis grown in northwestern Himalaya against Alternaria alternata. J. Plant Biochem. Biot, 21,44-50, 2012.

13.Koleva, I.I., Teris, A.B., Jozef, P.H., Linssen, A.G., and Lyuba, N.E. Screening of plant extracts for antioxidant activity: a comparative study on three testing methods. Phytochemistry Analysis, Vol. 13, pp.8-17, 2002.

14. Oyaizu, M. Studies on products of the browning reaction prepared from glucose amine. Japanese Journal of Nutrition, Vol. 44, pp.307-315, 1986.

15.Shirwaikar, A., Shirwaikar, A., Rajendran, K., and Punitha, I.S.R. In vitro antioxidant studies on the benzyl tetra isoquinoline alkaloid berberine. Biological \& Pharmaceutical Bulletin, Vol. 29, pp.19061910, 2006.

16.Lu, C.M., Zhang, C.Y.W., and Tao, M.X. Research of the effect of nanometer on germination and growth enhancement of Glycine $\max$ L. and its mechanism. Soybean Sci, Vol. 21,pp.168-172, 2002.

17.Doughari, J.H., El-mahmood, A.M., \& Tyoyina, I. (2008). Antimicrobial activity of leaf extracts of Senna obtusifolia (L.). African Journal of Pharmacy and Pharmacology, Vol. 2, pp.007-013, 2008.

18.Ruberto, G., and Baratta, M.T. Antioxidant activity of selected essential oil components in two lipid model systems. Food Chem, Vol. 69,pp. 167-174, 2000

19.Khadem, S., and Marles, J. Monocyclic phenolic acids; hydroxyand polyhydroxybenzoic acids: Occurrence and recent bioactivity studies. Molecules, Vol. 15,pp. 7985-8005, 2010. 
